\title{
APPLICATION OF BLENDED LEARNING MODEL COMBINED WITH MOBILE GAMES TO IMPROVETHE LEARNING OUTCOMES OF MEDICAL BIOLOGY STUDENTS
}

\author{
Dora Dayu Rahma Turista ${ }^{{ }^{*}}$, Muhammad Zulhariadi², Zulkarnain Gazali ${ }^{3}$ \\ ${ }^{1}$ STIKes Hutama Abdi Husada, Tulungagung \\ ${ }^{2}$ Biology Education Department - State Islamic University of Mataram \\ ${ }^{3}$ Biology Education Department - Nahdlatul Wathan Mataram University \\ *Corresponding author, e-mail: doraturistaofficial@gmail.com
}

\begin{tabular}{|c|c|}
\hline ARTICLE INFO & ABSTRACT \\
\hline $\begin{array}{l}\text { Article history } \\
\text { Received } 30^{\text {th }} \text { of Sept, } 2020 \\
\text { Revised } 03^{\text {rd }} \text { of Okt., } 2020 \\
\text { Accepted } 15^{\text {th }} \text { of Oct., } 2020 \\
\text { Published } 12^{\text {th }} \text { of Nov, } 2020 \\
\text { Keywords } \\
\text { Blended learning } \\
\text { Mobile game } \\
\text { Direct learning } \\
\text { Learning outcomes }\end{array}$ & $\begin{array}{l}\text { The Millennial generation is a term that is often used as a symbol of } \\
\text { the rapid use of products by people today. The use of mobile phones } \\
\text { connected to the internet is spread throughout the community. The } \\
\text { material in medical biology courses is considered difficult by most } \\
\text { students. The lecturer tries to make improvements to the teaching and } \\
\text { learning process by using learning models that are suitable for the } \\
\text { millennial generation, that is blended learning model combined with } \\
\text { mobile games. This study aims to determine the differences in } \\
\text { learning outcomes of students who use the blended learning model } \\
\text { combined with mobile games with the learning outcomes of students } \\
\text { who use the direct learning model in medical biology courses. This } \\
\text { research is a Quasi-Experimental studies that uses two sample groups } \\
\text { are the experimental group and the control group. The results of the } \\
\text { study were analyzed using Independent t-test statistical analysis. } \\
\text { Based on the research, there are significant differences in student } \\
\text { learning outcomes using the blended learning model combined with } \\
\text { mobile games with learning outcomes of students who use direct } \\
\text { learning in medical biology courses, where students use blended } \\
\text { learning models combined with mobile games have higher learning } \\
\text { outcomes when compared with students who use the direct learning } \\
\text { model. } \\
\text { Chis is an open access article under the CC-BY-SA license }\end{array}$ \\
\hline
\end{tabular}

\section{A. INTRODUCTION}

Millennial generation is a term that is often used today as a symbol of the rapid use of technology products by the people of today. Ericson's research report on 4000 respondents spread across 24 countries in 2016 showed that technology products will follow the lifestyle of millennials (Kominfo, 2016). The use of electronic media in the form of mobile phone is spread throughout the community. This also has an impact on the world of education. Conventional learning media has shifted and been replaced by electronic learning media. Internet as the media that connects all communication networks through electronic media can also be found in all places, both private property and public facilities. This condition is also supported by various providers that provide internet 
packages at affordable prices. As a result, students are faster in getting information through internet browsing.

Medical biology is one of the subjects taken by students of Diploma III Health Analyst and D III Nursing STIKes Hutama Abdi Husada Tulungagung in $1^{\text {st }}$ smester. The material in this course was considered difficult by most students. This can be seen from student learning outcomes, most of which are still under the minimum graduation criteria. Learning outcomes can be used as an indicator of the success of the teaching and learning process. Lectures are also responsible for determining the learning outcomes of their students. In this case, lecturer try to make improvements to the teaching and learning process by using learning models that are in suitable with the millennial generation, that is the Blended Learning model combined mobile game. Blended learning is a teaching and learning process that is done by combining face-to-face learning and online. Dwiyogo (2016) explains that learning based blended learning is learning that combines the strategies of delivering learning using face-to-face activities, computer-based learning (offline), and computers online (internet and mobile learning). The blended learning can take place by combining various sources physically and virtually (Sandi, 2012)

The learning process with blended learning models requires suitable media (Gede Sandi, 2012). Edmodo is one of the media that supports the blended learning model. Edmodo is a social networking based learning platform intended for educators, students, and parents of students. Edmodo is one of the most widely used web based e-learning applications (Septanto, 2015). Edmodo allows lecturers to safely create and maintain their own classroom community (Dharmawati, 2017). Edmodo facilitates teachers and students as a safe place to communicate, collaborate, share content and applications for learning, homework (PR) for students, virtual discussions, online tests, and grades (Kristiani, 2016). The reason for choosing Edmodo as a media is because it has a familiar menu that is similar to Facebook, so students are easier to operate. Tigowati, et al (2017)stated that Edmodo was created using the concept of social networking that refers to Facebook social networks. As an application for e-learning that is based on social media, edmodo can be accessed via laptop or android phone anywhere and anytime. Besides that Edmodo is also a free service, so it can be reached by all people.

Giving mobile games is also done to sharpen the thinking skill, increase memory, train fast thinking, and increase student motivation. The game is developed through apps geyser, which is a free online (web) based service. Apss geyser allows users to create applications based on android. The game contains multiple choice questions with five alternative answers. The game is installed on an Android phone of each student. This supports students to learn wherever and whenever, because the game can be played at any time. The use of mobile games can also increase students' learning motivation. The results of the study of Chrisnanda (2017) who concluded that learning with educational games is more interesting and can trigger students to study harder. Based on the description that has been described, the use of blended learning model combined with mobile games can create innovative, effective and efficient learning so that researchers are interested in conducting research entitled application of blended learning model combined with mobile games to improve the learning outcomes of medical biology students. This study aims to determine the differences in learning outcomes of students who use the blended learning learning 
model combined with mobile games with the learning outcomes of students who use the direct learning model in medical biology courses.

\section{B. METHOD}

This research is a Quasi-Experimental studies. The sample in this study was $1^{\text {st }}$ semester D III students of Medical Laboratory Technology as an Experimental group and $1^{\text {st }}$ semester D III Nursing students as a control group. The study was conducted on the same material taught by the same lecturer in the two classes. The experimental group applied the blended learning model combined with given mobile game based on android, while the control group applied direct (face to face) learning models without being given an mobile game based on android.

This research was carried out in 4 stages, they are the planning stage, the preparation stage, the implementation stage, and the final stage. The planning stage includes the initial survey, determining the title, and making a proposal. The preparation stage includes the selection of learning and development mobile game based on android, and making lesson plans. The implementation stage is carried out in accordance with the lesson plan that has been made and carried out at 4 times face to face and 1 time test.

The instrument in this study is a mobile game that contains multiple choice questions with 5 alternative answers. The results of the study data were analyzed by the Independent t-Test using compatible SPSS software in Windows to find out whether the learning outcomes between the experimental group and the control group differed significantly.

\section{RESULTS AND DISCUSSION}

\section{Result}

This research was conducted 4 learning times, consisting of 2 main material, namely the structure and function of cells and cell reproduction. Besides direct learning (face to face), the teaching and learning process was also carried out through e-learning using the Edmodo application. At the end of the 4th learning, students are given an mobile games based on android to install on each of their cellphones. The test is conducted at the next meeting. The test results were used as research results data grouped into 2, they are experimental group data (with blended learning model and given mobile games) and control group data (with face-to-face learning models without being given a mobile game). A summary of learning outcomes data from the two groups is presented in Table 3.1.

Tabel 3.1. Summary of Learning Outcomes Data

\begin{tabular}{lcc}
\hline \multirow{2}{*}{ Description } & \multicolumn{2}{c}{ Group } \\
\cline { 2 - 3 } & Experiment & Control \\
\hline Total & 31 & 31 \\
\hline The Highest Score & 97 & 94 \\
\hline The Lowest Score & 60 & 55 \\
\hline Average Score & 77 & 72 \\
\hline Standar deviation & 10.4 & 8.7 \\
\hline
\end{tabular}

Table 3.1 Shows that the experimental group had better learning outcomes compared to the control group. The data from the next study were analyzed by the Independent t-test. The results of the analysis show that $\operatorname{sig}(0.047)<\alpha(0.05)$ so that $\mathrm{H}_{0}$ is rejected and $\mathrm{H}_{1}$ is 
received, which means that the learning outcomes of the experimental group differ significantly from the learning outcomes of the control group.

\section{Discussion}

Based on the research that has been done it is known that the application of blended learning model combined with mobile game is proven to be able to improve the learning outcome of medical biology students. This is suitable with research result of Sandi (2012) which shows that the average score of chemistry learning outcomes of students who take part in blended learning is higher than the average score of students learning outcomes following direct learning. The results of research by Waty (2017) show that the application of blended learning model based edmodo can improve geography learning outcomes in the XI IPS 2 class of SMA Negeri 1 Banjarmasin.

Learning outcomes are not only influenced by the learning process in the classroom, but also influenced by the learning activities of students when outside the classroom. Blended learning can encourage students to study even outside of school hours, because it allows lecturers and students to interact wherever and whenever without being constrained by space and time. Fitriana (2018) states that in blended learning model is very possible for learning interactions from time and place (time and place flexibility). The blended learning model accommodates students and lecturers to have 24 hours a day for 7 days to give lectures to students both synchronously and asynchronously (Ali, 2013).

Learning outcomes are also influenced by the intensity of learning in the classroom. In this study the learning material was uploaded on Edmodo so that it can be accessed by students whenever and wherever they are. Edmodo allows students to study it repeatedly. Sandi (2012) states that students can improve the mastery of material by learning it repeatedly.

Student learning outcomes are also influenced by learning motivation. Edmodo also facilitates students to have discussions with friends or lecturer. Discussion can shape students' knowledge independently. This can support student centered learning methods. Lecturer play more roles as facilitators who support the creation of an interesting and pleasant learning atmosphere, so that student learning motivation is increases. This is suitable with the results of research by Manggabarani et al. (2016) which shows that the average score of motivation of students using the blended learning model is higher than the average score of motivation of students who use the direct learning model. Cognitive learning outcomes students with high motivation will be more maximal by using the blended learning model (Khoiroh, 2018). If the learning motivation is increase so the learning outcomes will be increase to.

Student independence also influences learning outcomes. Edmodo facilitates lecturers to be able to provide assignments in the form of a resume or quiz with a predetermined time range. This can support students to immediately do the assignments given by lecturers, and collect on time. The results of the study by Tigowati et al. (2017) showed that the application of e-learning based on edmodo was able to increase student' attractiveness, take lessons, make students pay more attention to lessons, make students more enthusiastic, more enthusiastic about learning, easy to do assignments and timely in collecting assignments. Blended learning strongly emphasizes the importance of discipline, 
creativity, and the responsibility of students for the tasks and problems they have (Sandi, 2012).

This study also uses mobile games based on android as a learning media. Generally, children and adolescents prefer to play rather than learn. The purpose of giving games to students is to foster students' interest in learning. Henry (2010) in Wijayanto (2017) explains that educational games basically refer to the content and purpose of the game itself, not included in the actual type of game and aim to attract children's interest while learning. The teaching and learning process using educational games is more interesting and stimulates students interest in learning more actively (Chrisnanda, 2017). That is will increase the student learning outcomes also. Tirtamayasandi (2018) in his research related to the design of learning media based on educational game on straight motion material at the junior level concluded that learning based on educational game was effective used to improve understanding of the material and to influence the improvement of learning outcomes.

Blended learning is a solution to overcome the shortcomings of direct (face to face) learning models and at the same time can be used as a solution to overcome the shortcomings of online learning. This is because the blended learning combines the two learning models, so that what is not completed in direct (face to face) learning can be completed with online learning, and what is not clear when the online learning process can be explained when doing direct (face to face learning). Lecturer and students can interact through e-learning and later discussed in the class. The results of the study Dobrzanski \& Brom (2008) show that the blended learning provides new teaching methods that can combine the benefits of traditional teaching and distance teaching. Blended learning combines wisely, relevantly, and precisely between potential face to face with the potential of information and communication technology that is very rapidly developing at this time. The most important advantage of the blended learning model is that the learning process becomes optimal, effective, economical, and allows educators and students to interact directly or remotely (Dobrzanski \& Brom, 2008). The advantages of blended learning have an effect on increasing student motivation so that learning outcomes also increase. Blended learning model has a good influence on social studies learning outcomes when compared with conventional learning models (Syahrin, 2015).

\section{CONCLUSION}

Based on the research that has been done, it can be concluded that there are significant differences in medical biology learning outcomes between students who use the blended learning model combined with mobile games with students who use direct (face to face) learning model. This difference shows that students who use the blended learning model combined with mobile games have an average value of medical biology courses that are higher when compared with the average value of students who use the direct (face to face) learning model.

Preferably the blended learning model is applied in all courses because it is in line with current technological developments, and does not reduce the essence of traditional learning but also benefits from online learning. 


\section{E. REFERENCES}

Ali, M. (2013). Analisis Dampak Implementasi Model Blended Learning (Kombinasi Pembelajaran Di Kelas Dan E-Learning) Pada Mata Kuliah Medan Elektromagnetik. Jurusan Pendidika Teknik Elektro UNY, 6, 22-35.

Chrisnanda, D. H. (2017). Efektifitas Pembelajaran dengan Game Edukasi Terhadap Minat Belajar Siswa (Studi Kasus: SMP N 2 Gunungwungkal, Pati) Artikel Ilmiah. Fakultas Teknologi Informasi, 1, 1-13.

Dobrzanski, L.A,. Brom, F. 2008. Blended Learning in Teaching Materials Science Subjects at Full Time Studies. International Scientific Journal, 34 (1): 57-60.

Dwiyogo, Wasis D. 2016. Pembelajaran berbasis Blended Learning-Model Rancangan Pembelajaran dan Hasil Belajar Pemecahan Masalah. Malang: Wineka Media.

Dharmawati. (2017). Penggunaan Media E-Learning Berbasis Edmodo dalam Pembelajaran English for Business QUERY. Jurnal Sistem Informasi, 1(1), 4349.

Fitriana, N. (2018). Penerapan Model Pembelajaran Blended Learning Pada Mata Kuliah Pemisahan Kimia Materi Kromatografi Untuk Meningkatkan Kualitas Belajar. Erudio Journal of Educational Innovation, 4(1), 46-54.

Gede Sandi. (2012). Pengaruh Blended Learning Terhadap Hasil Belajar Kimia Ditinjau Dari Kemandirian Siswa. Jurnal Pendidikan Dan Pengajaran, 241-251.

Henri Septanto. (2015). Elearning Menggunakan Edmodo Sebuah Aplikasi Pembelajaran Berbasis Web Pada Kelas Shift Di STMIK Bina Insani. Bina Insani Ict Journal, 2(2), 121-141.

Kominfo. 2016. Mengenal Generai Millenial. Retrieved from https://www.kominfo.go.id/content/detail/8566/mengenal-generasimillennial/0/sorotan_media, December 27.

Khoiroh, N. (2018). Pengaruh Model Pembelajaran Blended Learning dan Motivasi Belajar Terhadap Hasil Belajar Siswa Kelas VIII SMPN 1 Gumukmas. JURNAL $\begin{array}{llll}\text { PENELITIAN ILMU PENDIDIKAN, } & \text { 10(2), }\end{array}$ https://doi.org/10.21831/jpipfip.v10i2.13986.

Kristiani, D. (2016). E-learning dengan Aplikasi Edmodo di Sekolah Menengah Kejuruan. Prosiding Seminar Nasional Multi Disiplin Ilmu \& Call for Papers Unisbank, 3645.

Manggabarani, A.F et. al. 2016. The Effect of Blended Learning Models On Motivation and Student Achievement in X Senior High School 1 Pitumpanua (Study on Periodic System of Elements). Jurnal Chemica, 7 (2).

Syahrin, S.A. 2015. Pengaruh Model Pembelajaran Blended Learning Terhadap hasil Belajar Mata Pelajaran IPS SIswa Kelas 8 di SMPN 37 Jakarta (Unpublished Bachelor Thesis). Jakart: UIN Syarif Hidayatullah.

Tigowati, T., Efendi, A., \& Budiyanto, C. W. (2017). E-Learning Berbasis Schoology Dan Edmodo: Ditinjau Dari Motivasi Dan Hasil Belajar Siswa SMK. Elinvo 
(Electronics, Informatics, and Vocational Education), 2(1), 49-58. https://doi.org/10.21831/elinvo.v2i1.16416.

Tirtamayasandi, A.P. 2018. Perancangan Media Pembelajaran Berbasis Game Edukasi Untuk Meningkatkan pemahaman Materi Gerak Lurus IPA SMP (Unpublished bachelor thesis). Universitas Muhammadiyah Surakarta, Surakata.

Waty, N.L. 2017. Penerapan Model Blended Learning Berbasis Edmodo untuk Meningkatkan Hasil Belajar Geografi di Kelas XI IPS 2 SMA Negeri 1 Banjarmasin. Unpublished Master Thesis. Malang: Universitas Negeri Malang.

Wijayanto, E. (2017). Pengaruh Penggunaan Media Game Edukasi Terhadap Hasil Belajar IPA Siswa Kelas IV SDN Kajartengguli Prambon Sidoarjo. Jurnal Penelitian Pendidikan Guru Sekolah Dasar, 5(3), 254411. 